\title{
Speaking of Socio-Economic and Political Processes in the DPRK under Kim Jong-Un and Their Influence on Russian-North Korean Communication
}

\author{
Ekaterina Veka ${ }^{1} \&$ Vladimir Pecheritsa ${ }^{1}$ \\ ${ }^{1}$ Far Eastern Federal University, Vladivostok, Russian Federation \\ Correspondence: Ekaterina Veka, Far Eastern Federal University, Vladivostok, Russian Federation. Tel: \\ 79-1-4321-5632. E-mail: ekaterinaveka@mail.ru
}

Received: July 10, 2014 Accepted: August 8, 2014 Online Published: October 30, 2014

doi:10.5539/ass.v10n22p182 URL: http://dx.doi.org/10.5539/ass.v10n22p182

\begin{abstract}
The article analyzes North Korea domestic policy processes, such as socio-economic and political ones, under KIM Jong-un. The article shows that there are no signs of regime transformation which many experts prefer to declare. The survey proves that all processes initiated by KIM Jong-un within the country are neither more nor less than continuity with his predecessors' policy. At the same time KIM Jong-un protects his hard line in foreign policy, his course appears to be even more severe than his father's one at times. He is ready to show his will to the USA and even to Beijing. But relations between the DPRK and the Russian Federation are modifying. The last two years are characterized with appearance of the new touch to Russian-north Korean relations-they turn to economics keeping the political relations format. Two countries are seems to have even similar foreign policy concept in the face of common enemy.
\end{abstract}

Keywords: KIM Jong-un, domestic policy, North Korea, Russia

\section{Introduction}

It's been more than 2 years since KIM Jong-un came to power. All this time, despite experts' evaluations, the changes, showing no signs of weakening or liberalization of the political regime, do not stop. The young leader reinforces his authority, demonstrating that he is the one to determine country's course. KIM Jong-un stays Kim, his father's son, his grandfather's grandson; he maintains their policy and is guided by their principles. He is still supported by the elite KIM Jong-il created, carefully putting his own people in the administration circles.

\section{Discussion of Topic}

After coming to power KIM Jong-un aspires for economical reformations, the basis of which was founded by KIM Jong-il. For example the experiments are conducted in agrarian sphere in order to overcome food crisis. In April 2012 KIM Jong-un said: "Not a single North Korean citizen will have to tighten his belt anymore"...

For ideological basis of food program implementation the so called "instructions 6.28 " were used, in which it is spoken about significant reduction of the size of work cells-up to 6 persons, and that makes legal the work of separate peasant family. And besides, farmers now are hugely motivated to work hard-they are allowed to leave about $1 / 3$ of the crop yield for themselves.

The measures are taken in order to provide financial support for economical and agricultural sectors. According to South Korean Ministry of Unification, North Korean 2014 Budget is estimated at around \$7.1 million. According to North Korean Rodong Sinmun (Sinmun, 2014) the government had assigned 45.2\% of budget resources for economic development in 2013.

The South Korean Central Bank's data shows economic growth in North Korea in 2012 of 1,3\% which is 0,5\% more than in 2011 (The Bank of Korea, 2013). 2013 GDP of the DPRK was at 1.1\% (The Bank of Korea, 2014). That data is not official, but even the estimates are rather impressive.

In his New Year's speech KIM Jong-un appeals to the North Korean people with an unconventional statement: "With that very energy, that very enthusiasm that we entered the outer space with, we are to open up the new era in which the DPRK will be the mighty state with prosperous economy". 
The DPRK leader also pointed out the need of mechanization of agriculture, intensive use of agricultural chemicals and modern effective irrigation. These very directions were defined by KIM Il-sung in his work entitled "Theses on socialistic agrarian issue in our country".

At the same time during more than 2 years there're still staff rotations in the party, military and government, which some experts consider to be the "trimming" of unfavorable people and preparation for the regime transformation. Gradually introducing his men to the elite circles and shifting inner political weight from military staff to the ruling Party representatives, 30-year old leader demonstrates who runs this show. However he does not forget his father's testaments and relies on people, taught and raised by his father KIM Jong-il.

Noticeable difference from his predecessors is KIM Jong-un's behavior or so called format of representation leader's image to the people. The DPRK's leader tries to show him as being more open, more accessible for a regular citizen. He has already, unlike his father, given a number of public speeches. He'd also become the first North Korean ruler in 19 years to congratulate his compatriots with the New Year off the TV screen.

So, in the interview after the visit to DPRK on KIM Jong-un's invitation KIM Jong-il's former chef Kenji FUJIMOTO (The New York Times, 2012) notes that current head of State "appears a magnanimous leader to his people, as well as the chef", "the people have become lively and bright, and not afraid to show more cheerful faces".

"Mr. KIM seemed much more relaxed and cheerful than his aloof father ever was... The comrade general listened to everything I said and nodded even when I urged him to open up the republic to the world. KIM Jong-il never would have sat still and listened to views like that",-Kenji FUJIMOTO underlined.

Even his wife RI Sol-ju contributes to the maintenance of North Korean leader's new "democratic" style. For example, Kenji FUJIMOTO was surprised when young woman strode in the room next to KIM Jong-un. "She took a prominent role, because Mr. Kim's father had rarely taken any of his three known wives to such functions".

RI Sol-ju feels free when takes "the Shining Sun" KIM Jong-un's arm, everywhere accompanies him, each time appears in new stylish dresses, even in famous designers' ones. New leader' predecessors didn't take their wives to official meetings, even the image of the first ladies remained a mystery. Some experts suggest that the DPRK leader made revolution when he showed his wife to the world.

At the same time new leadership style of KIM Jong-un attains popularity among North Koreans (The Nautilus Institute for security and sustainability, 2012).

"He was first regarded as "young and inexperienced", but now as "young but able". Kim Jong-un's imitation of his grandfather's style also appears to have given people hope for a better future, reminding them of «those old good days» of the KIM Il-sung era versus the KIM Jong-il's. To deal with popular demands and legitimate his rule, he will have to be more accommodating and adaptive to new changes and opportunities than his father was".

In the recent times there're seen some signs of changes in social sphere in North Korea, which in conjunction with changes in other areas look like the regime transformation. These are the emergence of popular entertainments like waterpark, amusement parks, dolphinarium, riding club, luxury ski resort. World mass media are actively reporting how leader of immovably closed for the western culture country was congratulated by Disney cartoon characters and visited by famous American basketballer. Western press publish information about renovation Pyongyang's residential areas, new hospitals, gyms (Ryall, 2013), Google Maps detailing the DPRK cities maps (Seo, 2013), foreign tourists allowed to carry their cellphones. Witnesses say that there appeared more cars including foreign ones, a taxi, tents with drinks and ice cream. The great popularity in the country was received by the only pop group created on the personal instruction of KIM Jong-un. The female collective "Moranbon" for the first time appeared in short skirts and began to dance on a scene.

At the same time the new "democratic" behavior of the North Korean leader, his western interests and modern social structure can hardly be the signs of the country's facade breaking. The regime easing is unlikely to happen soon, no matter how the western media want it and announce it.

Some media, comparing KIM Jong-un with his predecessors, recall that KIM Jong-il was also attracted to the various western entertainments. He was an inveterate cinephile and had a huge movie collection, including digital media, enjoyed computer games, was "hanging out" in the Internet, preferred French cognac and snails. And even after that one could hardly call him a fan of the West, leading his country to the new life.

Maintaining gradual changes in the DPRK, KIM Jong-un is determined to protect his hard line in foreign policy. 
The North Korean leader had manifested him enough in more than 2 years. Pyongyang stirred up the world with its missile and nuclear manipulations, announcement of the "Holy War" with South Korea. His course appears to be even more severe than his father's one at times. KIM Jong-un unlike KIM Jong-il is ready to show his will even to Beijing.

Under KIM Jong-un's governance the DPRK becomes not just a small, unapproachable and discomforting country that needs to be sanctioned disarmed and broke down. It begins to be treated seriously. North Korea becomes a hard nut to crack for the Great Western Democratizer. "Pyongyang carefully studies American foreign policy, considering its past actions against Yugoslavia, Iraq, Afghanistan and Libya" (Klingner, 2013).

At this time relations between the DPRK and Russia are modifying. Both states have experienced many years of cooperation, share the border and, excluding the 90 s period, good dynamics of relations and understanding in politics. For many years Russia and North Korea supported each other in majority of issues in the UN Council. Moscow does not appeal to Pyongyang's nuclear-demonstrative approach to international politics, but it won't allow the West to bend North Korean regime to western will. It happened that Moscow joined the sanctions against North Korea but never had conversation on closing and limiting Russian-North Korean communications.

In 2012 when KIM Jong-un just started to get used to new role, Vladimir Putin promised to "continue active dialogue with the DPRK administration, develop neighborly relations, guiding Pyongyang towards the resolution of the nuclear problem at the same time (Putin, 2012).

However economic relations of two countries can hardly be called successful. The last two years are characterized with appearance of the new touch to Russian-north Korean relations-they turn to economics keeping the political relations format.

One of the signs of Russian-North Korean relations strengthening was the resolution of the debt problem. Russian government wrote off $90 \%$ of the DPRK debt. $\$ 9.87$ million to be precise. $10 \%$ that's left North Korea will be paying for the next 20 years. According to bilateral agreement all the payments send for the North Korean debt will be invested back into the DPRK's economy (Orlov, 2014).

Besides wide prospects for bilateral economic cooperation had opened up thanks to the recent decision of Intergovernmental Commission on trade-economic and scientific-technical cooperation between the Russian Federation and the DPRK, that was held at Vladivostok, that set the accounting mechanism using Russian rubles starting in June this year (Ministry for Development of Russian Far East, 2014).

According to DPRK Foreign Trade Minister RI Ryong Nam, these measures allow an increase in bilateral trade. It is suggested that Russia and North Korea will raise it to $\$ 1$ billion by 2020 .

Pyongyang also provided new prospects for Russian business by facilitating the visa regime for Russian investors and employees of Russian companies that work in North Korea. As Aleksandr Galushka, the head of the Ministry for Development of the Russian Far East, had stated, Russian investors will get unique conditions for realization of their projects in the DPRK-the commission is ready to escort them and individually lead to a logical conclusion and practical result. Interesting that such conditions are provided for Russians only, even Chinese do not get such an approach.

All in all, recent visits of Galushka, delegation of far eastern governors headed by residential Envoy to the Far Eastern Federal District Yury Trutnev (KCNA of DPRK, 2014) and Intergovernmental Commission are all serious steps in reinforcement of friendly and economical communications of Russia and North Korea. The Far East as a border zone between the two countries may become a platform for further development of their relations.

In his message to the Federal Assembly of December 122013 the Russian president Vladimir Putin (kremlin.ru, 2013) announced an upturn of the Russian Far East to be the nation's priority for the whole XXI century, remarking that "tasks to solve are unprecedented in their scale", so the steps taken by the Russian authority "has to be nonstandard".

Why then one of the steps could not become an adjustment of closer relations with neighboring North Korea?

"I am sure that the Russian Pacific pivot, the dynamic development of all our eastern territories will not just open the new possibilities in economy for us but also will give us additional tools for conduction of foreign policy"-the President kind of confirms these thoughts.

"I want to point out again: Russia is ready for the teamwork with all the partners to provide common, equal and undivided security"...

Even in the 90s notably, the period of certain stagnation of bilateral relations associated with the breakup of 
USSR, the regional connections were kept intact which was welcomed both on the level of the Russian federal center and Pyongyang authority.

That way for example Russian Primorsky Krai and the DPRK North Hamgyong Province have state land border of 17 kilometers. The regions are connected through a railway bridge called "Friendship". Here is the only pass gate through Russian-North Korean border.

As the main directions for cooperation wood processing, house building, agriculture, mining, medicine, trade, communication, mariculture and light industry are emphasized. Primorye-North Korean trade is characterized with positive dynamics-in 2013 it has been increased up to $70 \%$ in comparison with 2012 and estimated at $\$ 23.4$ million. Export was increased on $78 \%$ to $\$ 21.5$ million, import-on $10 \%$ to $\$ 1.9$ million (The Primorsky Krai Administration, 2014). An increase in trade was made possible largely due to an increase in oil and oil products exports to the DPRK. An import from the DPRK to Primorye consists mainly of machines, equipment and its parts.

Currently there's around 15-20 North Korean foreign trade agencies, companies, affiliates of economic ministries and departments in Primorsky Krai. Companies in Primorye are motivated to develop relations with the DPRK. Experts are discussing the offers of Rason trade zone authorities that were announced during November 2013 visit to Vladivostok, including the issues of tourism and transport logistics.

Also the Korean counterpart in august 2013 raised the issues of practically stopped since 2008 agriculture cooperation and the opening of specialized representation of it in Primorsky Krai. These days' North Koreans run an experienced agrarian manufacturing in Dalnerechensk municipal district.

Traditionally the main form of cooperation between Primorye and the DPRK is the usage of Korean work force in house building and agriculture due to the high work capacity and law abidance of the DPRK citizens.

Interstate agreements and projects are at high importance for Primorsky Krai and DPRK relationship. These are mainly trilateral projects offered by Russia on laying the gas pipe and high voltage lines through the DPRK's territory and connection of railways of Russia, the DPRK and Republic of Korea.

Realization of these projects providing developed infrastructure of a state border will have a positive effect on socio-economic situation in the border areas of Primorye and North Korea.

At the moment Hasan-Rajin railway stretch reconstruction project has been realized, being the part of Trans-Korean and Transsib railways connection project (The Primorsky Krai Administration, 2013).

The pier №3 in Rajin port was reconstructed to provide transit of Russian Siberian coal to eastern China ports at volume of 4 million tons.

Development of vehicle communication between Primorye and the DPRK may become a real step towards Korean business. The offer announced by Korean counterpart during the June Intergovernmental Commission meeting suggests an increase in cargo transit between two regions. However the need in additional railway bridge between Hasan and Tumangan arises (The Primorsky Krai Administration, 2014).

Along with economic cooperation the friendly relation between Russia and North Korea are reinforced with a "soft power"-cultural and sports relations development.

That way since 2004 supported by general consulate of the DPRK there're exhibitions of the DRPK's arts and crafts held in all the municipal areas of Primorsky Krai, 6-12 times per year (PrimaMedia.ru, 2014).

The DPRK's filmmakers take part in international Pacific Meridian festival, a "visiting card" of Vladivostok and Primorsky Krai (RIA Novosti, 2012).

Primorsky Krai regularly holds international taekwondo tournaments with the DPRK athletes participating. In March 2014 another Plan on sports exchanges for the current year between two sides was signed.

In 2012-2013 on the Far Eastern Federal University basis 27 North Koreans were studying. 11 students, 1 graduate student, 15 trainees. In 201325 the DPRK citizens entered FEFU.

Cooperation in a cleric sphere has also been set. Since 2006 the clergy of Vladivostok diocese regularly visits the DPRK invited by Orthodox Committee to participate in Pyongyang Holy Trinity Church festivities and celebrations. This church was built by a personal order of KIM Jong-il. According to the DPRK's ex-leader's plan it was a memorial to Russian-Korean friendship.

Speaking of Russian-North Korean relations development in a context of Primorye and the DPRK cooperation one should consider 30 thousand Russian Koreans living on Primorsky Krai territory. They are likely to be interested in deeper relations between Russian and both states of the Korean peninsula. 
Russia and North Korea notably in the light of recent events on the international arena have similar foreign policy concept. Warming of relations between two countries has increased after escalation of tension between Moscow and the West. Common enemy makes you better friends, as everybody knows.

In his message to the Federal Assembly made after Crimea joined Russia, the president Vladimir Putin made it clear that Russian state is able and ready to withstand western permissiveness (kremlin.ru, 2014). Talking about Crimea situation the state leader implied Russian-American relation for the past 2 decades.

"Our western partners lead by the USA prefer ... to be guided not by international right but the right of the powerful one. They had believed in them being chosen and exclusive, believed that they are allowed to decide the fate of the world... They act as they please-using force here and there against sovereign states...",-the President announced.

These very actions of the Russian leader were met with approval in North Korea. In his message the DPRK ambassador in Moscow KIM Yong-jae remarked that Ukrainian events are the evidence of western countries ignoring the international law principles (Interfax, 2014).

"The last alarming events in Ukraine provoked by the USA and Western countries according to their prearranged conspiracy scenarios, persuasively show who is the reason for all the planet's troubles, who seeks to overthrow sovereign state and cruelly denies people's right for self-determination",-ambassador said.

The diplomat also remarked that North Korea is happy with Russian intent "to stand for national interests and sovereignty and building strong state".

Another words, in the eyes of the North Koreans Russian authority stands out for proper account of legitimate security interests and economic development of all counties. And in particular it does not put the blame on the DPRK for tensions on the Korean peninsula but condemns the West.

For North Korea such announcements from the President Putin are the signs of Russia being comprehensive and maybe even a little close to Juche ideology, calling for people of each country to fight not only against aggression and enslavement but also for consistent protection of their independence.

Interesting fact in 2008 then the Russian President Dmitry Medvedev addressed the Federal Assembly with these words-"the basis for our policy has to be an ideology with a person in its center" (kremlin.ru, 2008). And that's practically word to word citation of the article 3 of Socialistic Constitution of the DPRK-"the DPRK is guided in its actions by the ideas of Juche-world view with a person put in the center..." (VKPB, 2014).

That way the USA's ideological confrontation is another key factor in quickening of Russia and the DPRK rapprochement.

Besides now Moscow is offered a great chance to move Beijing and go forward in relations with the DPRK not only in politics but in economic sphere as well. In its turn Pyongyang is suited to step a little aside from "elder brother's" overwhelming custody.

JANG Sung-taek's execution that occupied the post of the DPRK vice-chairman of the National Defence Commission and was the uncle of North Korean leader, made Beijing to rather cool down to his "little brother". Being one of the most influential political figures JANG Sung-taek was Chinese henchman and had been illegally selling it the DPRK natural resources for pennies.

Moreover China authorities were abruptly dissatisfied with Pyongyang's manipulations in the end of 2012-beginning of 2013, related to long range missile test and the $3^{\text {rd }}$ nuclear test.

\section{Conclusion}

In spite of the internal changes North Korea remains to be closed country relying on its own forces and ready to counter the West permissiveness. At the same time the country is ready to strengthen its relations with Russia and, first of all, the economic ones. One of the most important steps towards the DPRK and Russia rapprochement may become a visit of KIM Jong-un. It will be symbolic and indicative if Russia would become the first country for him to go to for the first time of his 2 year rule.

\section{References}

Agropark project in Mikhailovskiy district will be implemented with North Korean specialists. (2014). The Primorsky Krai Administration. Retrieved from http://primorsky.ru/news/common/65282/?sphrase_id $=338713$

All-Union Communist Party Bolsheviks. (1972). Retrieved from http://vkpb.ru/old/kndr 
Arts and crafts exhibition opened in Artem. (2014). PrimaMedia.ru. Retrieved from http://primamedia.ru/news/ primorye/14.04.2014/350303/vistavka-dekorativno-prikladnogo-iskusstva-kndr-s-dnem-solntsa-otk

Asmolov K. Kim Jong-un got rid of his uncle. (2013). MK.ru. Retrieved from http://www.mk.ru/politics/article /2013/12/09/956838-kim-chen-yin-izbavilsya-ot-svoego-dyadi

Chef's Redemption tells of a softening North Korea. (2012). The New York Times. Retrieved from http://www.nytimes.com/2012/08/25/world/asia/kim-family-chefs-redemption-suggests-a-softening-north-k orea.html?_r=1\&

Department of international cooperation and tourism development of Primorsky Krai. (2014). The Primorsky Krai Administration.

Development of new tours to North Korea is discussed in Primorye. (2013). The Primorsky Krai Administration. Retrieved from http://primorsky.ru/news/common/56929/?sphrase_id=341980

DPRK will provide Russian investors with exclusive conditions for work, ease visa regime for business trips and move to settlements in rubles. (2014). Ministry for Development of Russian Far East. Retrieved from http://minvostokrazvitia.ru/press-center/news_minvostok/?ELEMENT_ID=1999

Gross Domestic Product Estimates for North Korea in 2012. (2013). The Bank of Korea. Retrieved from http://bok.or.kr/contents/total/eng/boardView.action?menuNaviId=1959\&boardBean.brdid=12202\&boardB ean.menuid $=1959$

Gross Domestic Product Estimates for North Korea in 2013. (2014). The Bank of Korea. Retrieved from http://bok.or.kr/contents/total/eng/boardView.action?menuNavild=634\&boardBean.brdid=14033\&boardBe an.menuid $=634$

Kim Yong Nam Meets Russian Deputy PM. (2014). Korean Central News Agency of DPRK. Retrieved from http://www.kcna.co.jp/index-e.htm

Klingner B. North Korea Sees Weak US Resolve on Syria. (2013). The Heritage Foundation. Retrieved from http://www.heritage.org/research/commentary/2013/9/north-korea-sees-weak-us-resolve-on-syria

Lankov, А. (2014). Ланьков A. Kim Jong-un eradicates Chinese agents. Retrieved from http://rus.ruvr.ru/2014 _01_31/Kim-CHen-In-vikorchevivaet-kitajskuju-agenturu-6610

Message of the Russian Federation President. (2014). kremlin.ru. Retrieved from http://news.kremlin.ru/news 120603

Message to the Federal Assembly of the Russian Federation President. (2012). kremlin.ru. Retrieved from http://news.kremlin.ru/transcripts/19825

Message to the Federal Assembly of the Russian Federation President. (2008). kremlin.ru. Retrieved from http://archive.kremlin.ru/appears/2008/11/05/1349_type63372type63374type63381type82634_208749

Orlov A., Romanova K. Kim family were forgiven a debt. (2014). Retrieved from http://www.gazeta.ru/business/ 2014/02/19/5916573

Pacific Meridian Film Festival Program included three films of the DPRK. (2012). RIA Novosti. Retrieved from http://ria.ru/culture/20120816/724626194.html

Power Transition in North Korea and Kim Jong Un's Leadership Style: Prospects for Reform and Opening. (2012). The Nautilus Institute for security and sustainability. Retrieved from http://nautilus.org/napsnet/ napsnet-policy-forum/power-transition-in-north-korea-and-kim-jong-uns-leadership-style-prospects-for-ref orm-and-opening/\#axzz39aI7loBL

Primorye seeks to strengthen its communication with DPRK. (2012). The Primorsky Krai Administration. Retrieved from http://primorsky.ru/news/common/4219/?sphrase_id $=347295$

Putin V. Russia and changing world. (2012). Retrieved from http://www.kremlinstrategia.ru/index.php? option=com_content\&view=article \&id=123:-q-q\&catid=35:2012-04-27-10-43-20\&Itemid=79

Pyongyang: Ukrainian events are the evidence of western countries ignoring the international law principles. (2014). Interfax. Retrieved from http://www.interfax.ru/world/364793

Report on implementation of State budget for 2013 and Sate budget for 2014. (2014). Rodong Sinmun. Retrieved from https://nkfood.files.wordpress.com/2014/04/rodong-sinmun-2014-budget.pdf 
Ryall J.. Kim Jong-un: 10 ways North Korea's 'Dear Leader' is different. (2013). The telegraph. Retrieved from http:/www.telegraph.co.uk/news/worldnews/asia/northkorea/10522136/Kim-Jong-un-10-ways-North-Kore as-Dear-Leader-is-different

Seo, Y. (2013). Google releases detailed map of North Korea, gulags and all. Retrieved from http:/www.washingtonpost.com/blogs/worldviews/wp/2013/01/28/google-releases-detailed-map-of-north-k orea-gulags-and-all

\section{Copyrights}

Copyright for this article is retained by the author(s), with first publication rights granted to the journal.

This is an open-access article distributed under the terms and conditions of the Creative Commons Attribution license (http://creativecommons.org/licenses/by/3.0/). 